\title{
MICROPROPAGATION OF SOME NEW PEACH ROOTSTOCKS
}

\section{AZZA I. MOHAMED}

\author{
Horticulture Res. Instit., ARC, Giza - Egypt
}

(Manuscript received $1^{\text {st }}$ October 2014)

\begin{abstract}
Two experiments were conducted in 2011 and 2012 seasons on two newly introduced peach rootstocks, namely Garnem and Cadaman (which are widely used in Europe) in addition to the wellknown Nemaguard peach rootstock for comparison. The aim of this study is to optimize tissue culture protocol for propagation of the rootstocks under study. Results indicated that Nodal cuttings were better than shoot-tips in regard to aseptic culture (without contamination after 10 days) during establishment stage. However after one month, the three rootstocks gave rise to $100 \%$ survival percentage. Meanwhile number of leaves on Nemaguard rootstock was significantly the greatest. During proliferation stage, Garnem produced the highest shoot number, while Cadaman rootstock produced significantly the lowest shoot number. Regarding the effect of BA supplementation, it was found that BA at $2.0 \mathrm{ml} / \mathrm{I}$ resulted in the longest shoots. During rooting stage, $2.0 \mathrm{mg} / \mathrm{l} \mathrm{GA} 3$ significantly gave the longest shoots. At root formation, there were no significant differences between the 3 rootstocks concerning root number, rooting percentage and root length. $0.1 \mathrm{mg} / \mathrm{l} \mathrm{IBA}$ incorporated in half MS medium strength gave the highest significant values for the same traits. During acclimatization stage, Garnem rootstock achieved the highest significant survival ratio, while half strength Murashige and skoog (MS) medium resulted in better survival ratio, plant height and number of leaves. Sand + peat moss potting mixture achieved better survival ratio, plant height and number of leaves than Sand + Vermiculite. Protein banding patterns profile data proved the presence of band with molecular weight 20.094 k Da in Garnem rootstock, which may be responsible for high number of shoots and survival ratio. This band was absent in other rootstocks.
\end{abstract}

Keywords: Peach rootstock, micropropagation , acclimatization , proliferation, rooting, establishment, protein profile.

\section{INTRODUCTION}

The peach ( Prunus persica (L.) Batsch) is a popular fruit and considered one of the most important fruits in the world. Many new rootstocks for stone fruits have been developed in the past 20 years. High productivity, efficiency requires tree survival, managed vigor, and increased marketable yields over the expected life Span of the orchard. The growers' choice of root-stock is often as important, if not more so, than the choice of scion variety whenever peaches, plums and apricots are grown in soils 
having high bulk density, parasitic nematodes, root rot fungal pathogens, or other edaphic or replant problem ( Reighard 2005).

The local market is supplied with different new peach rootstocks such as "Cadaman " a peach hybrid between [ Prunus persica X Prunus davidiana ] and "Garnem" (G X N 15) a peach - almond hybrid. Those rootstocks have root-Knot resistance and compatible with peach and plum ( Reighard 2005). The" Cadaman" peach rootstock was preliminary characterized as resistant to plum pox virus (PPV) ( Polak and Oukropec , 2010), resistance against root knot nematods, good adaptation to Mediterranean environments and high cropping efficiency with peach and nectarine cultivars ( Pinochet ,2009). Chilling requirement seems to be low in the range of 400 to 600 chill units compared to these of "Garnem" (Kester and Asay, 1986). "Cadaman" is a patented Hungarian-French-bred vegetative peach rootstock resistant to nematodes, widely used in Europe (Bozenna et al., 2008). "Nemaguard" peach is resistant to root-Knot nematodes (Meloidogyne incognita and M. javanica), but has high chilling requirements 825 hrs at $\leq 7{ }^{\circ} \mathrm{C}$ (Ferguson and chaparro, 2004).

Propagation of these rootstocks is important to supply commercial nurseries to increase total stone fruit cultivated area in Egypt which is $49.209 \mathrm{Ha}$ ( Feddan $=0.4$ $\mathrm{Ha}$ ) with an approximate yearly production of 476.849 Tons (6\% total fruit production) as recorded by El- Mghraby et al.,( 2007).

Micropropagation is an important technique of propagation. The objective of this study is to optimize a tissue culture protocol for propagation of some stone fruit rootstocks namely Garnem , Cadaman and Nemagured. Comparative biochemical genetic study was done for three rootstocks under study.

\section{MATERIALS AND METHODS}

\section{2-A- Micropropagation of Rootstocks under study:-}

This study was conducted at the plant tissue laboratory of the Horticulture Research Institute, Ministry of Agriculture, Giza ,Egypt, during two successive seasons of $2011 \& 2012$.

During the active growth period from March to July , 2011 growing terminal shoots and one Nodal cuttings of about $3 \mathrm{~cm}$ length were collected from one year old seedlings of Garnem, Cadaman and Nemaguard peach rootstocks (Prunus persica.) and the leaves were gently removed without injuring the buds. They were washed with running tap water and few drops of Tween 20 for 2 hours, The shoots were sterilized in commercial bleach "Clorox " (5.25 \% Sodium hypochlorite ) with 
concentration of $10 \%$ for $15 \mathrm{~min}$ (Fouad et al. 1995) then rinsed three times in a sterilized distilled water each for ten minutes to remove any residues of Clorox.

2-A-1- Establishment stage:-

This stage was aimed to determine the suitable explants type (shoot tip \& nodal cuttings ) on MS medium (Murashige and skoog 1962 ) (Table, 1) supplemented with $30 \mathrm{~g} / \mathrm{l}$ sucrose, $0.01 \mathrm{mg} / \mathrm{I}$ ( Indolebutyric acid ) , $0.2 \mathrm{mg} / / \mathrm{BA}$ (6- Benzyl adenine) and Purified agar ( Bacto - Difo agar ) at $7 \mathrm{~g} / \mathrm{L}$ [ Fouad et al. 1995].

The $\mathrm{pH}$ of the medium was adjusted to $5.6-5.7$ before sterilizing in autoclave at $121^{\circ} \mathrm{C}$ for $20 \mathrm{~min}$. All cultures were incubated under conditions of $25^{\circ} \mathrm{C} \pm 2$ and photoperiod of 16 hours (fluorescent light 2000 Lux), followed by 8 hours darkness. After 4 weeks, data of aseptic cultures $\%$, survival \%, shoot length and number of leaves were recorded.

Table 1. Formulation of MS plant culture medium.

\begin{tabular}{|c|c|c|c|}
\hline Constituent & $\begin{array}{c}\text { Concentration in } \\
\text { culture medium } \\
(\mathrm{mg} / \text { liter })\end{array}$ & Constituent & $\begin{array}{c}\text { Concentration in } \\
\text { culture medium (mg } \\
\text { / liter) }\end{array}$ \\
\hline \multicolumn{2}{|l|}{ Macro elements } & \multicolumn{2}{|l|}{ Microelements } \\
\hline $\mathrm{KNO}_{3}$ & 1900 & $\mathrm{MnSO}_{4} \cdot 4 \mathrm{H}_{2} \mathrm{O}$ & 22.30 \\
\hline $\mathrm{NH}_{4} \mathrm{No}_{3}$ & 1650 & KI & 0.83 \\
\hline $\mathrm{MgSo} 4.7 \mathrm{H}_{2} \mathrm{O}$ & 370 & $\mathrm{H} 3 \mathrm{Bo} 3$ & 6.20 \\
\hline $\mathrm{CaCl}_{2} \cdot 2 \mathrm{H}_{2} \mathrm{O}$ & 440 & $\mathrm{ZnSO}_{4} .7 \mathrm{H}_{2} \mathrm{O}$ & 8.60 \\
\hline $\mathrm{KH} 2 \mathrm{PO} 4$ & 170 & $\mathrm{CuSO}_{4} \cdot 5 \mathrm{H}_{2} \mathrm{O}$ & 0.025 \\
\hline \multicolumn{2}{|l|}{ Organic Supplement } & $\mathrm{Na}_{2} \mathrm{MoO}_{4} \cdot 2 \mathrm{H}_{2} \mathrm{O}$ & 0.250 \\
\hline Nicotinic acid & 0.50 & $\mathrm{CaCl}_{2} \cdot 6 \mathrm{H} 2 \mathrm{O}$ & 0.025 \\
\hline Pyridoxine-Hcl & 0.50 & Iron Source & \\
\hline Thiamine- $\mathrm{Hcl}$ & 0.10 & $\mathrm{FeSO}_{4} \cdot 7 \mathrm{H}_{2} \mathrm{O}$ & 27.80 \\
\hline Myo-inositol & 100 & \multirow[b]{2}{*}{$\mathrm{Na} 2 \mathrm{EATA}$} & \multirow[b]{2}{*}{37.30} \\
\hline Glycine & 2.00 & & \\
\hline
\end{tabular}

2- A-2-Proliferation "shoot multiplication"stage:-

Plant materials needed for this stage were provided from the newly emerged shoots throughout the previous stage i.e. establishment. Hence, regenerated shoots were collected and cultured individual, on solid MS medium supplemented with 100 mg / I myoinosital, $0.4 \mathrm{mg} / \mathrm{I}$ thiamin- $\mathrm{HCl}$ and $30 \mathrm{~g} /$ I sucrose. BA (6- benzyl adenine) was added with different concentration 1,2 and $3 \mathrm{ml} / \mathrm{l}$. Media were autoclaved at 1.5 $\mathrm{kg} / \mathrm{cm}^{2}$ and $121^{\circ} \mathrm{C}$ for $20 \mathrm{~min}$, then left to cool for $24 \mathrm{hrs}$ before used. All cultures 
were incubated under the culture condition. After 4 weeks, data on shoot number, shoot length $(\mathrm{cm})$, fresh weight $(\mathrm{g})$ and dry weight $(\mathrm{g})$ were recorded after the $4^{\text {th }}$ subculture.

2- A-3- Rooting Stage: - This stage was divided to two sub stages.

2- A-3-(a) - Shoot elongation:

The proliferated shoots of each rootstock were cultured on MS medium supplemented with $30 \mathrm{~g} / \mathrm{l}$ sucrose, purified Bacto-Difico agar and different concentrations of $\mathrm{GA}_{3}(2.0,4.0,6.0 \mathrm{mg} / \mathrm{l})$.

2- A-3-(b) - Root formation:

The elongated plantlets were cultured on two strength of MS medium (half and full). Media were supplemented with (30 g/l) sucrose, (7g / $)$ purified Bacto-Difico agar and different levels of IBA $(0.1,0.5,1.0 \mathrm{mg} / \mathrm{l})$.

$\mathrm{pH}$ of the rooting medium was adjusted to 5.6-5.8 before autoclaving and cultures were incubated under the same culture condition. Elongated shoots were cultured in jars containing $(40 \mathrm{ml})$ of the abovementioned rooting media, then incububated for one week in dark followed by 3 weeks in light. Four weeks after incubation, rooting $\%$, root number, root length $(\mathrm{cm})$, callus and shoot length $(\mathrm{cm})$ of each treatment were recorded.

2- A- 4 - Acclimatization stage:-

Produced plantlets were washed with tap water then Dipped in Rhizolix solution $(1.0 \mathrm{~g} / \mathrm{l})$ as fungicide for $(10 \mathrm{~min})$ just before transplanting in $(300 \mathrm{ml})$ plastic pots containing autoclaved transplanting medium [ Sand + Vermiculite $(1: 1)$ ] and [ Sand + peat moss $(1: 1)$ ] and maintained in green house for four weeks.

Pots were arranged then covered with polyethylene bags to maintain high relative humidity around the plants in green house. After two weeks, the polyethylene bags were partially removed to allow air circulation and later removed after other two weeks from those plantlets. Plantlets were irrigated with half strength MS maintenance medium (free hormone medium) during the period of hardening. Irrigation was applied depending on the requirement of plantlets .Pests and disease control program was followed as recommended. Data were recorded after two month of transplanting as follow:

1 - Survival percentage.

2 - Plant length $(\mathrm{cm})$.

3 - Number of Leaves / plant. 
2- A - 5- Statistical analysis:-

Explants and plantlets were arranged in split-plot or split- split plot design. Data obtained were statistically analyzed according to Duncans multiple rang test, (Dncan 1955).

\section{2- B - Biochemical fingerprint studies:-}

2- B - 1- Protein related index:

Fractionation electrophoresis was performed under identical conditions on sodium dedocyl sulphate polyacrlamide gel( SDS - PAGE) ( $12 \% \mathrm{~W} / \mathrm{V}$ ) vertical slab using BIORAD Techware $1.5 \mathrm{~mm}$ according to the modified method by Studier (1973) . The molecular weights of proteins were estimated relative to marker, a wide range molecular weight protein (Ferments com).

2- B - 2- Gel analysis:-

Gel was photographed, scanned and analyzed using Gel Doc 2000 Biosystem.

\section{RESULTS AND DISCUSSION}

\section{3- A - Micro propagation of rootstocks:-}

\section{3-A-1- Establishment stage:-}

Data of table (2) show the effect of rootstock and explants type and their interaction on ....

*Aseptic culture \% (without contamination after 10 days):-

Regarding the specific effect of rootstock. Data clearly showed that there were no significant differences between rootstocks under study during the two growing seasons.

However, explant type significantly influenced aseptic culture percentage. Nodal cuttings had more aseptic culture \% than shoot tips in the two growing seasons.

The interaction between explants type and rootstock type reveals that nodal cuttings of Garnem and Nemaguard rootstocks had more aseptic percentage than those of Cadaman rootstock. Shoot tips of the three rootstocks failed to achieve any percentage of aseptic culture at all in the first season. In the second season, all nodal cutting of the rootstocks and shoot tips of Nemaguard had the highest aseptic culture percentage.

In this concern, Sliva et al. (2003) found that shoot apices of GF677 rootstock gave lower contamination rates than lateral buds. 
*Survival \% (without contamination after one month):-

With regard to the specific effect of explants type and rootstock type and their interaction, results showed that all rootstocks gave rise to $100 \%$ survival\% in both seasons.

In this respect, Silva et al. (2003) found that shoot apices of GF677 peach rootstock gave higher survival rates than lateral buds.

*Shoot length:

Data obtained in table (2) revealed that for the specific effect of rootstocks, Cadaman had the longest shoot length in the first season, meanwhile Cadaman and Garnem had the longest values in this respect in the second season. Nemaguard rootstock had the lowest significant values in the two seasons.

Concerning shoot length as affected by explants type, nodal cuttings produced longest shoots than shoot tips.

Concerning the interaction effect between explants type and rootstocks, nodal cuttings of Cadaman gave the highest values in the two seasons. Shoot tips of Nemaguard resulted in the shortest shoots in the two seasons, in addition to shoot tips of Nemaguard in the second season.

*Number of leaves:

Regarding the specific effect of rootstock, the numbers of leaves on Nemaguard rootstock were significantly the greatest in the two seasons.

Referring to the effect of explant type, shoot tips produced higher number of leaves than in nodal cuttings in the two seasons.

The interaction effect between explants type and rootstocks showed that shoot tips of Nemaguard rootstock was significantly the best in producing leaves in the two seasons.

In a similar work on number of leaves, Eldeen et al. (1998) mentioned that shoot tips of Nemaguard showed a better response than nodal explants during establishment.

\section{3-A-2-Proliferation "Shoot multiplication" stage:-}

* Shoot number:

In this concern, the effect of the two studied factors i.e. rootstock type and the concentration of growth regulator $B A(1,2$ and $3 \mathrm{mg} / \mathrm{l})$, in addition to the interaction between them were investigated pertaining to the number of the resultant shoots. Data obtained four weeks later from $4^{\text {th }}$ subcultures of multiplication stage are present in table (3) and figures (1), (2) and (3) respectively. 
Regarding the effect of rootstock type it is clear that Garnem produced the highest shoot numbers in the two seasons. Shoot numbers produced by Nemaguard had the lowest significant value in the two seasons.

Concerning the effect of different concentration of BA, there were no significant differences between different concentrations under study in the two seasons.

The interaction effect between rootstock type and concentration of growth regulator BA revealed that the best shoot number was induced from media containing 1.0, 2.0 and $3.0 \mathrm{mg} / \mathrm{l} \mathrm{BA}$ with "Garnem" rootstock in the first season and from the same media with both Garnem and Cadaman in the second one.

In parallel with these results, Kamali et al. (2001) showed that the addition of more than $1 \mathrm{mg} /$ I BA concentration increased proliferation of GF677 rootstock. Meanwhile, Unek et al. (2011) found that the highest number of shoots was produced by medium containing $1.0 \mathrm{mg} /$ I BAP. Higher BAP (2.0 \& $4.0 \mathrm{mg} / \mathrm{l})$ concentration decreased number of shoots with Ganrem rootstock.

*Shoot length:

As for the effect of rootstock type Cadaman rootstock significantly produced longer shoots than the other rootstocks in the two seasons.

Concerning shoot length as affected by the different concentrations of BA, it was obvious that $2.0 \mathrm{mg} / \mathrm{l}$ in the two seasons and $1.0 \mathrm{mg} / \mathrm{l}$ in the second season resulted in the longest shoots.

The interaction effect between rootstock type and concentration of growth regulator BA clearly show that, $2.0 \mathrm{mg} / \mathrm{l}$ significantly resulted in the longest shoots with Cadaman rootstock in the two seasons. Cadaman treated with BA or $1.0 \mathrm{mg} / \mathrm{l}$ in the first season or with $2.0 \mathrm{mg} / \mathrm{I}$ in the second one also shared in the highest position.

In this concern, Fouad et al. (1995) using Mit-Gamr and Nemaguard rootstocks mentioned that increasing the concentration of $\mathrm{BA}$ in the multiplication media decreased the length of these shoots.

\section{*Fresh weight:}

Regarding the effect of rootstocks on fresh weight, Cadaman had more fresh weight than other rootstocks in the first season. But, in the second season there were no significant difference between the 3 rootstocks.

Concerning the effect of different BA concentration, $3.0 \mathrm{mg} / \mathrm{l}$ resulted in the best significant fresh weight in the two seasons. Meanwhile, BA at $1.0 \mathrm{mg} / \mathrm{l}$ produced also the heaviest fresh weight. 
The interaction effect clearly showed that $1.0 \& 3.0 \mathrm{mg} / \mathrm{l} \mathrm{BA}$ resulted in the highest significant value of fresh weight with Cadaman rootstock in the two seasons. $3.0 \mathrm{mg} / \mathrm{l}$ on Garnem rootstock resulted also in the heaviest F.W., in the two seasons and the highest value of this character in Nemaguard in the second season only.

* Dry weight:

Garnem rootstock produced significantly the heaviest dry weight in the first season. Differences between the 3 rootstocks were not significant in the second season.

BA at $1.0 \& 2.0 \mathrm{mg} / \mathrm{l}$ produced heavies dry shoots in the second season. Results of the first season were no significant.

The interaction effect showed that $2.0 \mathrm{mg} / \mathrm{l}$ gave the best results with Garnem concerning dry weight. $1.0 \mathrm{mg} / \mathrm{l}$ also produced dry weight with Cadaman and Nemaguard rootstocks.

\section{3-A-3-Rooting stage:-}

3-A-3- (a) - Shoot elongation:-

Data in table (4) exhibited the effect of different concentrations of $\mathrm{GA}_{3}$ (2.0, $4.0, \& 6.0 \mathrm{mg} / \mathrm{l})$ on shoot.

*Shoot Length:

The effect of rootstock type: - Garnem rootstock gave the best shoot length in the first season. In the second season Cadaman rootstock was superior to both Garnem and Nemaguard rootstocks.

The effect of using different concentration of $\mathrm{GA}_{3}$ on shoot length: - $\mathrm{GA}_{3}$ at 2.0 or $4.0 \mathrm{mg} / \mathrm{l}$ significantly gave the longest shoots in the first season. In the second one only $\mathrm{GA}_{3}$ at $2.0 \mathrm{mg} / \mathrm{l}$ was the best.

The interaction between rootstock type and different concentration of $\mathrm{GA}_{3}$ : Using $\mathrm{GA}_{3}$ at $2.0 \mathrm{mg} / \mathrm{l}$ in the first season with Cadaman gave the longest shoots, while in the second season $4.0 \mathrm{mg} / \mathrm{I} \mathrm{GA}_{3}$ resulted in the longest shoots of Garnem rootstock.

The obtained data are in harmony with results of Reeves et al. (1985) who stated that shoots of peach and plum rootstocks treated with $12.5 \mathrm{mg} / \mathrm{GA}_{3}$ produced elongated shoots.

*Callus:

The effect of rootstock type: Nemaguard rootstock significantly produced largest amount of callus around shoots in the two seasons.

Concerning the effect of $\mathrm{GA}_{3}$ concentration: $4.0 \& 6.0 \mathrm{mg} / /$ gave higher amounts of callus in the first season. In the second season, $\mathrm{GA}_{3}$ at $6.0 \mathrm{mg} / \mathrm{l}$ produced the heaviest callus. 
The interaction between rootstock type and $\mathrm{GA}_{3}$ concentration: - $6.0 \mathrm{mg} / \mathrm{l} \mathrm{GA} 3$ with Nemaguard rootstock produced the largest callus in the two seasons.

\section{3-A-3- (b) - Root formation:}

Data in table (5) and figure (4) showed the effect of rootstock type, concentration of IBA and medium strength and their interactions on root number, rooting percentage and root length.

*Root number:

Concerning the effect of rootstock type: There were no significant differences between the three rootstocks in the two seasons.

The effect of using different concentrations of IBA: Using IBA at $0.1 \mathrm{mg} / \mathrm{l}$ gave the highest significant root number in the two seasons.

The effect of medium strength: Using MS at half strength resulted in higher number of roots than in full strength medium.

For the interaction between rootstock type and medium strength, Garnem on half strength medium gave the highest significant values in the two seasons. In the second season Garnem on half strength medium shaped in the highest values of root numbers.

The interaction between medium strength and IBA concentration: IBA at $0.1 \mathrm{mg} / \mathrm{l}$ plus half strength medium resulted in the best significant values of root numbers in the two seasons.

The interaction between rootstock type and IBA concentration: Garnem grown on $0.1 \mathrm{mg} / \mathrm{l}$ gave the highest root numbers in the 2 seasons, while Cadaman grown on the same medium gave the highest root number in the second season only.

The interaction between rootstock type, medium strength and IBA concentration: Garnem grown on half strength medium supplement with $0.1 \mathrm{mg} / \mathrm{I}$ IBA gave the highest significant number of roots in the two seasons. Cadaman in the same conditions shared also in the highest values.

On the contrary, Fouad et al., (1995) mentioned that increasing auxin concentration positively affected the average number of roots/explant of Nemaguard and Mit-Ghamr rootstocks.Also, Fayek et al. (2008) found that IBA at $2 \mathrm{mg} / \mathrm{l}$ induced the optimum balance between number and length of roots in Nemaguard, Mit Ghamr, Okinawa, Nemared and GF677 peach rootstocks.

*Rooting percentage:

Regarding the effect of rootstock type: There was no significant differences between the three rootstocks in the two seasons.

The effect of different concentrations of IBA: $0.1 \mathrm{mg} / \mathrm{l}$ IBA gave the best significant rooting percentage in the two seasons. 
Concerning the effect of medium strength: Half strength resulted in higher values than full strength.

The interaction between rootstock type and medium strength: Using half strength medium gave the highest significant values with Garnem and Cadaman rootstocks in the two seasons.

The interaction between medium strength and IBA concentration: $0.1 \mathrm{mg} / \mathrm{I}$ IBA with half strength medium gave the best significant values compared to other treatments.

The interaction between rootstock type and IBA concentration: Garnem rootstock cultured on medium supplement with $0.1 \mathrm{mg} / \mathrm{l}$ IBA gave the highest significant rooting percentage in the 2 seasons while, Cadaman grown in the same conditions gave the highest value in the second season only.

To the interaction between rootstock type, medium strength and IBA concentration : Growing Garnem on half strength medium supplanted with IBA at 0.1 $\mathrm{mg} / \mathrm{l}$ gave the best results in the two seasons, while Cadaman grown in the same conditions gave the highest value in the first season only.

These result agreed with Kitto and Young (1981) findings. They indicated that the addition of auxin to the medium is fundamental for the root induction.

*Root length:

Regarding the effect of rootstock type: A there was no significant differences between the three rootstocks in the two seasons.

Referring to the effect of different concentrations of IBA: $0.1 \mathrm{mg} / \mathrm{l}$ gave the highest significant values in the two seasons.

The effect of medium strength: half strength gave longer roots than full strength in the two seasons.

The interaction between rootstock type and medium strength indicated that Cadaman grown on 1/2 MS produced the longest roots in both seasons. Garnem grown on the same medium strength gave also the longest roots in the first season only.

The interaction between medium strength and IBA concentration: Using half strength medium supplemented with $0.1 \mathrm{mg} / \mathrm{I}$ IBA resulted in the longest roots in the 2 seasons.

Regarding the interaction between rootstock type and IBA Concentrations: Cadaman treated with IBA at $1 \mathrm{mg} / \mathrm{l}$ in both seasons and Garnem having the same treatment in the second season only gave the longest roots.

The interaction between rootstock type, medium strength and IBA concentrations showed that applying $0.1 \mathrm{mg} / \mathrm{l}$ to Cadaman rootstock cultured on half 
strength medium gave the longest roots significantly in the 2 seasons. The same result was obtained by Garnem in the 1 season. These observations are partially in agreement with findings of Ahmed et al., (2003) who stated that the best root system of GF677 rootstock was developed on half strength MS media supplemented with 3 $\mathrm{mg} / \mathrm{I}$ IBA.

\section{3-A-4-Acclimatization stage:-}

Data being presented in table (6) reflect with the effect of rootstock treatments, medium strength, potting mixture and their interactions on survival ratio, plant height and number of leaves.

*Survival ratio:

The effect of rootstock type: that Garnem rootstock achieved the highest significant survival ratio in the two seasons, while Cadaman rootstock revealed the same result in the second season only. On the other hand, Nemaguard rootstock had the lowest significant value in the two seasons.

The effect of medium strength: Medium half strength resulted in better survival ratio than in full strength one.

The effect of potting mixture: $\{$ Sand + Peat moss $\}$ medium achieved better survival ratio than $\{$ Sand + Vermiculite $\}$ medium in the two seasons.

For the interaction between rootstock treatments and medium strength: Garnem rootstock cultured on half strength medium had the highest significant survival ratio in the two seasons, while Cadaman rootstock showed the same rank in the second season only.

The interaction between medium strength and potting mixture plantlets which were produced on half strength medium and cultured on \{Sand + Peat moss $\}$ mixture had higher significant survival ratio in the two seasons.

The interaction between rootstock type and potting mixture: Garnem rootstock cultured on $\{$ Sand + Peat moss $\}$ had the highest significant survival ratio in the two seasons.

The interaction between rootstock treatment, medium strength and potting mixture: Garnem rootstock grown on half strength medium and cultured on \{Sand + peat moss $\}$ mixture had the highest survival ratio in the two seasons. Cadaman grown on the same conditions had also the highest survival ratio in the first season only. In this respect, Balla and kirilla $\{2006\}$ mentioned that the in vitro rooted plants of Cadaman rootstock could be successfully acclimatized under greenhouse conditions. Different degrees of survival are often found in various phases of acclimatization which for some clones makes it rather difficult to optimize micro propagation procedures \{Balttistini et al., 2002\}. 
*plant height:

The effect of rootstock type: There was no significant differences between the three rootstocks in regard to plant height in the first season. In the second season, plant height of Garnem and Cadaman were higher than that in Nemaguard.

The effect of medium strength: Half strength medium resulted in higher plants in the two seasons than full strength.

The effect of potting mixture : $\{$ Sand + peat moss $\}$ resulted in higher plants than the other medium.

The interaction between rootstock type and medium strength: The highest plants were obtained of Cadaman which produced from half strength medium in the two seasons, in addition to Garnem rootstock on half medium gave better plant height in the two seasons than the other strength.

To the interaction between medium strength and potting mixture: Plantlets which were produced from half strength medium and cultured on \{Sand + peat moss $\}$ mixture were significantly the highest in the two seasons.

The interaction between rootstock type and potting mixture, Granem and Nemaguard rootstocks cultured on Sand + peat moss had the highest significant survival ratio in the 2 seasons, while Cadaman rootstock obtained the same rank in the first season only.

The interaction between rootstock type, medium strength and potting mixture: Garnem and Cadaman rootstocks grown on half strength medium and potted in sand + peat moss mixture were the highest plants in the two seasons. Nemaguard rootstock grown and potted in the same conditions achieved the highest position in the second season only.

*Number of leaves:

The effect of Rootstock type: Nemaguard and Cadaman rootstocks had significantly more number of leaves in the first season. In the second season there were no significant differences between the three rootstocks.

The effect of medium strength: Half strength medium resulted in more number of leaves than in full strength one.

The effect of potting mixture: \{Sand + peat moss\} mixture gave higher significant number of leaves than $\{$ Sand + Vermiculite $\}$ mixture in the two seasons.

The effect of the interaction between rootstock type and medium type: In the first season Nemaguard rootstock on half strength medium had the highest significant number of leaves. But, in the second season there is no significant differences between 3 rootstock in the same medium. 
The effect of the interaction between medium strength and potting mixture: plantlets produced from half strength medium and grown on \{Sand + peat moss $\}$ mixture had the highest significant number of leaves in the two seasons.

The effect of the interaction between rootstock type and potting mixture: In the first season, Nemaguard grown on \{Sand + peat moss $\}$ mixture had the highest significant number of leaves. In the second season, Cadaman grown on the same mixture had superior significant number of leaves than the others.

The effect of interaction between rootstock type, medium strength and potting mixture: Nemaguard rootstock cultured on half strength medium and grown on $\{$ Sand + peat moss $\}$ mixture was the best number of leaves in the two seasons. Cadaman rootstock cultured on half strength and grown on \{Sand + peat moss in the second season achieved also the highest category. However, Saeed $\{2005\}$ mentioned that the plantlet of Hansen 2168 peach rootstock attained the highest survival percentage, shoot length and number of leaves when transplanted in plastic pots containing vermiculite, peat moss and Sand mixture $\{1: 1: 1\}$.Also, Fayek et al. ( 2008) working on in vitro peach rootstocks found that plantlet of Nemared had the highest survival percentage on length of shoot during acclimation in vermiculite: peat moss : sand medium at 1:1:1 volume. Meanwhile, Nemeguard ones produced the highest of leaves and shoots. 
Table 2. Specific and interaction effects of explants type on Aseptic culture\%, survival \%,shoot length(cm) and No. of leaves during the establishment stage of three peach rootstock in 2011 and 2012 seasons.

\begin{tabular}{|c|c|c|c|c|c|c|c|c|c|c|c|c|}
\hline \multirow[b]{2}{*}{ Rootstock } & \multicolumn{2}{|c|}{ Aseptic culture \% } & \multirow[b]{2}{*}{${ }^{*}$ Mean } & \multicolumn{2}{|c|}{ Survival \% } & \multirow[b]{2}{*}{ *Mean } & \multicolumn{2}{|c|}{ Shoot length (cm.) } & \multirow[b]{2}{*}{${ }^{*}$ Mean } & \multicolumn{2}{|c|}{ No. of leaves } & \multirow[b]{2}{*}{${ }^{*}$ Mear } \\
\hline & Shoot tip & $\begin{array}{l}\text { Nodel } \\
\text { cutting }\end{array}$ & & Shoot tip & $\begin{array}{l}\text { Nodel } \\
\text { cutting }\end{array}$ & & Shoot tip & $\begin{array}{l}\text { Nodel } \\
\text { cutting }\end{array}$ & & Shoot tip & $\begin{array}{l}\text { Nodel } \\
\text { cutting }\end{array}$ & \\
\hline \multicolumn{13}{|c|}{2011} \\
\hline Garnem & $0.00 c$ & $26.37 a$ & $13.18 \mathrm{~A}$ & $100.00 a$ & $100.00 a$ & $100.00 \mathrm{~A}$ & $1.77 \mathrm{c}$ & $2.57 \mathrm{~b}$ & $2.17 \mathrm{~B}$ & $5.33 b$ & $5.00 \mathrm{~b}$ & $5.17 \mathrm{~B}$ \\
\hline Cadaman & $0.00 \mathrm{c}$ & $16.67 \mathrm{~b}$ & $8.33 \mathrm{~A}$ & $100.00 a$ & $100.00 a$ & $100.00 \mathrm{~A}$ & $2.37 \mathrm{~b}$ & $3.63 a$ & $3.00 \mathrm{~A}$ & $5.33 b$ & $3.67 b$ & $4.50 \mathrm{~B}$ \\
\hline Nemaguard & $0.00 \mathrm{c}$ & $21.21 a b$ & $10.61 \mathrm{~A}$ & $100.0 a$ & $100.0 \mathrm{a}$ & $100.00 \mathrm{~A}$ & $1.43 c$ & $2.37 b$ & $1.90 \mathrm{~B}$ & $9.33 a$ & $5.00 \mathrm{~b}$ & $7.17 \mathrm{~A}$ \\
\hline **Mean & $0.00 \mathrm{~B}$ & $21.41 \mathrm{~A}$ & & $100.00 a$ & $10.00 \mathrm{a}$ & & $1.86 \mathrm{~B}$ & $2.86 \mathrm{~A}$ & & $6.67 \mathrm{~A}$ & $4.56 \mathrm{~A}$ & \\
\hline \multicolumn{13}{|c|}{2012} \\
\hline Garnem & $0.00 \mathrm{c}$ & $15.27 a b$ & $7.63 \mathrm{~A}$ & $100.00 a$ & $100.00 a$ & $100.00 \mathrm{~A}$ & $1.93 b$ & $2.83 a$ & $2.38 \mathrm{~A}$ & $4.67 b$ & $3.67 c$ & $4.17 \mathrm{~B}$ \\
\hline Cadaman & $4.17 \mathrm{bc}$ & $10.23 a-c$ & $7.20 \mathrm{~A}$ & $100.00 a$ & $100.00 a$ & $100.00 \mathrm{~A}$ & $2.23 b$ & $3.27 a$ & $2.75 \mathrm{~A}$ & $5.33 b$ & $3.67 c$ & $4.50 \mathrm{~B}$ \\
\hline Nemaguard & $8.33 a-c$ & $19.32 a$ & $13.82 \mathrm{~A}$ & $100.0 a$ & $100.0 a$ & $100.00 \mathrm{~A}$ & $1.27 \mathrm{c}$ & $1.90 \mathrm{~b}$ & $1.58 \mathrm{~B}$ & 8.33a & $5.00 \mathrm{~b}$ & $6.67 \mathrm{~A}$ \\
\hline$* *$ Mean & $4.17 \mathrm{~B}$ & $14.94 \mathrm{~A}$ & & $100.00 \mathrm{~A}$ & $10.00 \mathrm{~A}$ & & $1.81 \mathrm{~B}$ & $2.67 \mathrm{~A}$ & & $6.11 \mathrm{~A}$ & $4.11 \mathrm{~B}$ & \\
\hline
\end{tabular}

$*, * *$ Refer to specific effect of rootstock type and explants type, respectively. Capital and small letters were used for distinguishing between values of specific and interaction effects respectively. Whereas, means in each column followed by the same letter/s are not significantly different at $5 \%$ level.

Aseptic culture: - means without contamination \% after after10 days.

Survival \%:- means without contamination \% after one month. 
Table 3. Specific and interaction effects of different concentrations of BA on shoot number, Shoot length(cm),Fresh weight (g.) and Dry weight (g.)during the multiplication stage of three peach rootstock in 2011 and 2012 seasons.

\begin{tabular}{|c|c|c|c|c|c|c|c|c|c|c|c|c|c|c|c|c|}
\hline \multirow{3}{*}{ Rootstock } & \multicolumn{3}{|c|}{ Shoot number } & \multirow{3}{*}{ *Mean } & \multicolumn{3}{|c|}{ Shoot length $(\mathrm{cm})}$. & \multirow{3}{*}{ *Mean } & \multicolumn{3}{|c|}{ Fresh weight (g.) } & \multirow{3}{*}{ *Mean } & \multicolumn{3}{|c|}{ Dry weight (g.) } & \multirow{3}{*}{ *Mean } \\
\hline & \multicolumn{3}{|c|}{ BA } & & \multicolumn{3}{|c|}{ BA } & & \multicolumn{3}{|c|}{ BA } & & \multicolumn{3}{|c|}{ BA } & \\
\hline & $\begin{array}{c}(1.0 \\
\mathrm{mg} / \mathrm{l})\end{array}$ & $\begin{array}{c}(2.0 \\
\mathrm{mg} / \mathrm{l})\end{array}$ & $\begin{array}{c}(3.0 \\
\mathrm{mg} / \mathrm{l})\end{array}$ & & $\begin{array}{c}(1.0 \\
\mathrm{mg} / \mathrm{l})\end{array}$ & $\begin{array}{c}(2.0 \\
\mathrm{mg} / \mathrm{l})\end{array}$ & $\begin{array}{c}(3.0 \\
\mathrm{mg} / \mathrm{l})\end{array}$ & & $\begin{array}{c}(1.0 \\
\mathrm{mg} / \mathrm{l})\end{array}$ & $\begin{array}{c}(2.0 \\
\mathrm{mg} / \mathrm{l})\end{array}$ & $\begin{array}{c}(3.0 \\
\mathrm{mg} / \mathrm{l})\end{array}$ & & $\begin{array}{c}(1.0 \\
\mathrm{mg} / \mathrm{l})\end{array}$ & $\begin{array}{c}(2.0 \\
\mathrm{mg} / \mathrm{l})\end{array}$ & $\begin{array}{c}(3.0 \\
\mathrm{mg} / \mathrm{l})\end{array}$ & \\
\hline \multicolumn{17}{|c|}{2011} \\
\hline Garnem & $6.67 a b$ & $7.00 a$ & $7.00 a$ & $6.89 \mathrm{~A}$ & $1.43 \mathrm{~d}$ & $1.73 b$ & $1.07 \mathrm{f}$ & $1.41 \mathrm{~B}$ & $0.380 \mathrm{~d}$ & $0.243 \mathrm{e}$ & $0.550 \mathrm{a}-\mathrm{c}$ & $0.391 \mathrm{~B}$ & $0.137 a-d$ & $0.230 a$ & $0.123 \mathrm{~b}-\mathrm{e}$ & $0.163 \mathrm{~A}$ \\
\hline Cadaman & $4.67 c d$ & $5.00 \mathrm{bc}$ & $5.00 \mathrm{bc}$ & $4 . .89 \mathrm{~B}$ & $1.67 \mathrm{bc}$ & $2.07 a$ & $1.27 \mathrm{e}$ & $1.67 \mathrm{~A}$ & $0.567 a b$ & $0.473 \mathrm{~b}-\mathrm{d}$ & $0.643 a$ & $0.561 \mathrm{~A}$ & $0.170 \mathrm{a}-\mathrm{c}$ & $0.097 c-e$ & $0.130 \mathrm{a}-\mathrm{d}$ & $0.132 A B$ \\
\hline Nemaguard & $3.00 \mathrm{~d}$ & $3.67 \mathrm{~cd}$ & $3.00 \mathrm{~d}$ & $3.22 \mathrm{C}$ & $1.97 a$ & $1.53 \mathrm{~cd}$ & $0.57 \mathrm{~g}$ & $1.36 \mathrm{~B}$ & $0.437 \mathrm{~cd}$ & $0.213 e$ & $0.430 \mathrm{~cd}$ & $0.360 \mathrm{~B}$ & $0.220 \mathrm{ab}$ & $0.027 \mathrm{e}$ & $0.053 \mathrm{de}$ & $0.100 \mathrm{~B}$ \\
\hline$* *$ Mean & $4.78 \mathrm{~A}$ & $5.22 \mathrm{~A}$ & $5 . .00 \mathrm{~A}$ & & $1.69 \mathrm{~A}$ & $1.78 \mathrm{~A}$ & $0.97 \mathrm{~B}$ & & $0.461 \mathrm{~A}$ & $0.310 \mathrm{~B}$ & $0.541 \mathrm{~A}$ & & $0.176 \mathrm{~A}$ & $0.118 \mathrm{~A}$ & $0.102 \mathrm{~A}$ & \\
\hline \multicolumn{17}{|c|}{2012} \\
\hline Garnem & $5.00 \mathrm{ab}$ & $6.00 a$ & $6.33 a$ & $5.78 \mathrm{~A}$ & $1.40 \mathrm{c}$ & $1.77 a b$ & $1.10 \mathrm{~d}$ & $1.42 \mathrm{~B}$ & $0.193 c$ & $0.250 \mathrm{bc}$ & $0.363 a-c$ & $0.269 \mathrm{~A}$ & $0.067 \mathrm{~d}$ & $0.313 a$ & $0.100 \mathrm{~cd}$ & $0.160 \mathrm{~A}$ \\
\hline Cadaman & $5.67 a$ & $5.67 a$ & $4.67 a b$ & $5.33 \mathrm{~A}$ & $1.63 \mathrm{~b}$ & $1.93 a$ & $1.07 \mathrm{~d}$ & $1.54 \mathrm{~A}$ & $0.387 a b$ & $0.347 a-c$ & $0.337 a-c$ & $0.357 \mathrm{~A}$ & $0.213 a-c$ & $0.133 b-d$ & $0.100 \mathrm{~cd}$ & $0.149 \mathrm{~A}$ \\
\hline Nemaguard & $3.33 b$ & $3.33 b$ & $3.67 \mathrm{~b}$ & $3.44 \mathrm{~B}$ & $1.73 b$ & $1.93 a$ & $0.67 \mathrm{e}$ & $1.44 \mathrm{AB}$ & $0.190 \mathrm{c}$ & $0.277 \mathrm{bc}$ & $0.483 a$ & $0.317 \mathrm{~A}$ & $0.237 a b$ & $0.130 b-d$ & $0.100 \mathrm{~cd}$ & $0.156 \mathrm{~A}$ \\
\hline **Mean & $4.67 \mathrm{~A}$ & $5.00 \mathrm{~A}$ & $4.89 \mathrm{~A}$ & & $1.59 \mathrm{~B}$ & $1.88 \mathrm{~A}$ & $0.94 C$ & & $0.257 \mathrm{~B}$ & $0.291 B$ & $0.394 \mathrm{~A}$ & & $0.172 \mathrm{~A}$ & $0.192 \mathrm{~A}$ & $0.100 \mathrm{~B}$ & \\
\hline
\end{tabular}

$*, * *$ Refer to specific effect of rootstock type and different concentrations of BA, respectively. Capital and small letters were used for distinguishing between values of specific factors and the interaction effects respectively. Whereas, means in each column followed by the same letter/s are not significantly different at $5 \%$ level. 

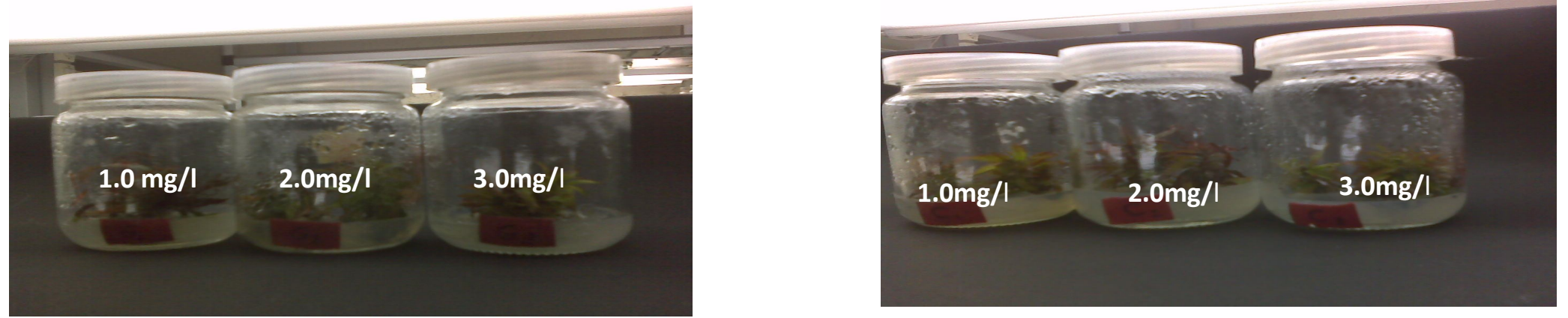

Figure 1. Effect of BA with different concentration on Garnem peach Fig 2. Effect of BA with different concentration on Cadaman peach rootstock during the multiplication stage. rootstock during the multiplication stage.

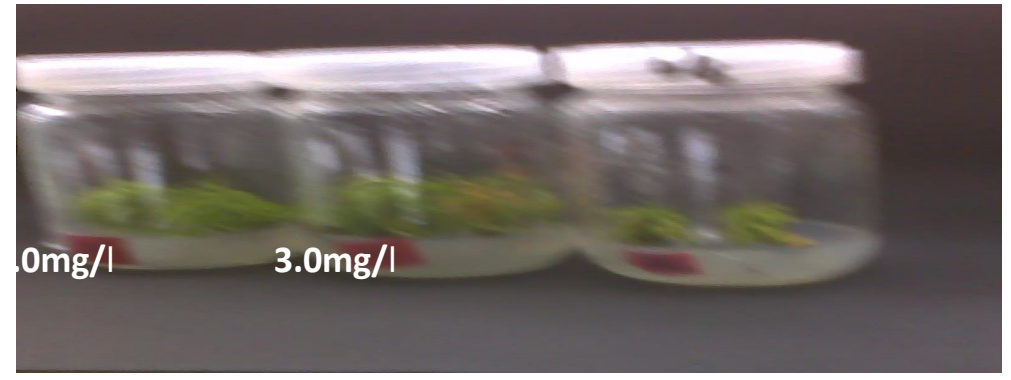

Figure 3. Effect of BA with different concentrations on Nemaguard peach rootstock during the multiplication stage. 
Table 4. Specific and interaction effects of different concentration $\mathrm{GA}_{3}$ on shoot length $(\mathrm{cm})$, callous during rooting stage of three peach rootstock in 2011 and 2012 seasons.

\begin{tabular}{|c|c|c|c|c|c|c|c|c|}
\hline \multirow{3}{*}{ Rootstock } & \multicolumn{3}{|c|}{ Shoot length (cm.) } & \multirow{3}{*}{ *Mean } & \multirow{2}{*}{\multicolumn{3}{|c|}{$\begin{array}{c}\text { Callous } \\
\mathrm{GA}_{3}\end{array}$}} & \multirow{3}{*}{ *Mean } \\
\hline & \multicolumn{3}{|c|}{$\mathrm{GA}_{3}$} & & & & & \\
\hline & $\begin{array}{c}(2.0 \\
\mathrm{mg} / \mathrm{I})\end{array}$ & $\begin{array}{c}(4.0 \\
\mathrm{mg} / \mathrm{l})\end{array}$ & $\begin{array}{r}(6.0 \\
\mathrm{mg} / \mathrm{l})\end{array}$ & & $\begin{array}{r}(2.0 \\
\mathrm{mg} / \mathrm{l})\end{array}$ & $\begin{array}{r}(4.0 \\
\mathrm{mg} / \mathrm{l})\end{array}$ & $\begin{array}{c}(6.0 \\
\mathrm{mg} / \mathrm{l})\end{array}$ & \\
\hline \multicolumn{9}{|c|}{2011} \\
\hline Garnem & $5.60 \mathrm{~b}$ & $5.50 \mathrm{~b}$ & $4.73 c$ & $5.20 \mathrm{~A}$ & $0.00 \mathrm{~d}$ & $0.267 a$ & $0.133 b c$ & $0.133 \mathrm{AB}$ \\
\hline Cadaman & $6.50 a$ & $4.67 \mathrm{c}$ & $4.50 c$ & $4.76 \mathrm{~B}$ & $0.00 \mathrm{~d}$ & $0.133 \mathrm{bc}$ & $0.200 \mathrm{bc}$ & $0.111 B$ \\
\hline Nemaguard & $3.50 \mathrm{e}$ & $4.10 \mathrm{~d}$ & $3.67 e$ & $4.30 \mathrm{C}$ & $0.067 \mathrm{~cd}$ & $0.200 a b$ & $0.267 a$ & $0.178 \mathrm{~A}$ \\
\hline **Mean & $5.28 \mathrm{~A}$ & $5.22 \mathrm{~A}$ & $4.76 \mathrm{~B}$ & & $0.022 B$ & $0.200 \mathrm{~A}$ & $0.200 \mathrm{~A}$ & \\
\hline \multicolumn{9}{|c|}{2012} \\
\hline Garnem & $4.93 \mathrm{~cd}$ & $7.20 \mathrm{a}$ & $4.80 \mathrm{~d}$ & $4.90 \mathrm{~B}$ & $0.00 \mathrm{e}$ & $0.200 \mathrm{~b}$ & $0.100 \mathrm{~cd}$ & $0.100 \mathrm{~B}$ \\
\hline Cadaman & $6.30 \mathrm{~b}$ & $5.17 \mathrm{c}$ & $4.00 \mathrm{e}$ & $5.36 \mathrm{~A}$ & $0.033 \mathrm{de}$ & $0.067 \mathrm{de}$ & $0.167 \mathrm{bc}$ & $0.089 \mathrm{~B}$ \\
\hline Nemaguard & $3.47 \mathrm{fg}$ & $3.70 f$ & $3.27 \mathrm{~g}$ & $4.02 \mathrm{C}$ & $0.033 \mathrm{de}$ & $0.100 \mathrm{~cd}$ & $0.333 a$ & $0.156 \mathrm{~A}$ \\
\hline$* *$ Mean & $5.64 \mathrm{~A}$ & $5.16 \mathrm{~B}$ & $3.48 \mathrm{C}$ & & $0.022 \mathrm{C}$ & $0.122 \mathrm{~B}$ & $0.200 \mathrm{~B}$ & \\
\hline
\end{tabular}

$*$, **Refer to specific effect of rootstock type and different concentrations of $\mathrm{GA}_{3}$, respectively. Capital and small letters were used for distinguishing between values of specific factors and the interaction effects respectively. Whereas, means in each column followed by the same letter/s are not significantly different at $5 \%$ level.

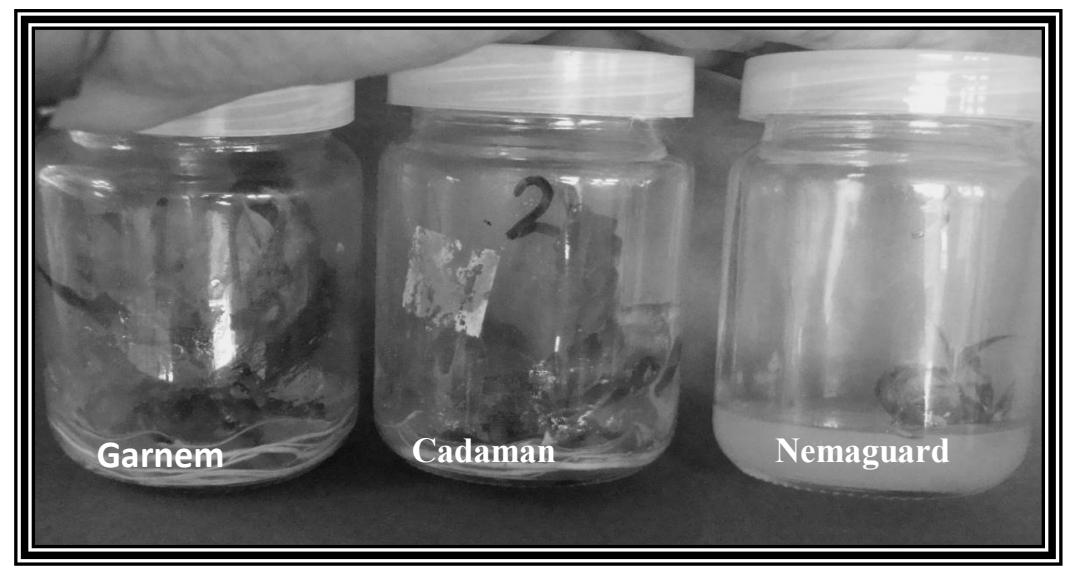

Figure 4. Effect $0.1 \mathrm{mg} / \mathrm{I}$ IBA root formation on peach rootstocks under study during root formation. 
Table 5. Specific and interaction effects of different concentrations of IBA $\mathrm{mg} / \mathrm{l}$ on root number, rooting percentage and root length (cm) during rooting stage of three new peach rootstocks in 2011 and 2012 seasons.

\begin{tabular}{|c|c|c|c|c|c|c|c|c|c|c|c|c|c|}
\hline \multirow{2}{*}{\multicolumn{2}{|c|}{ Rootstock }} & \multicolumn{4}{|c|}{ Roots Number } & \multicolumn{4}{|c|}{ Rooting (\%) } & \multicolumn{4}{|c|}{ Root length $(\mathrm{cm})$} \\
\hline & & $0.1 \mathrm{mg} / / * *$ & $0.5 \mathrm{mg} / / * *$ & $1.0 \mathrm{mg} / /^{* *}$ & Mean $A \times B$ & $0.1 \mathrm{mg} / /^{* *}$ & $0.5 \mathrm{mg} / \mathrm{l} * *$ & $1.0 \mathrm{mg} / \mathrm{l}^{* *}$ & Mean $A \times B$ & $0.1 \mathrm{mg} / /^{* *}$ & $0.5 \mathrm{mg} / \mathrm{l}^{* *}$ & $1.0 \mathrm{mg} / / * *$ & Mean $A \times B$ \\
\hline Garnem & Full Strength & $\frac{1.67 \mathrm{c}}{3.007}$ & $\begin{array}{l}0.67 e \\
0.32 f \\
\end{array}$ & $0.00 \mathrm{~g}$ & $0.78 \mathrm{BC}$ & $33.33 \mathrm{~b}$ & $8.33 \mathrm{C}$ & $0.00 \mathrm{c}$ & $13.89 \mathrm{C}$ & $5.67 \mathrm{bc}$ & $0.67 \mathrm{e}$ & $0.00 \mathrm{e}$ & $2.11 \mathrm{BC}$ \\
\hline Garnem & Half Strength & $3.00 \mathrm{a}$ & $0.33 \mathrm{f}$ & $0.00 \mathrm{~g}$ & $1.11 \mathrm{~A}$ & $75.00 \mathrm{a}$ & $8.33 c$ & $0.00 \mathrm{c}$ & $27.78 \mathrm{~A}$ & $12.00 \mathrm{a}$ & $1.00 \mathrm{e}$ & $0.00 \mathrm{e}$ & $\frac{4.33 \mathrm{~A}}{\mathrm{Mean}(\mathrm{A}) *}$ \\
\hline & $A \times C$ & $2.33 \mathrm{~A}$ & $0.50 \mathrm{D}$ & $0.00 \mathrm{E}$ & $\begin{array}{c}\text { Mean }(\mathrm{A}) * \\
0.94 \mathrm{~A}\end{array}$ & $54.17 \mathrm{~A}$ & $8.33 \mathrm{C}$ & $0.00 \mathrm{D}$ & $\begin{array}{c}\text { Mean }(\mathrm{A}) * \\
20.83 \mathrm{~A}\end{array}$ & $8.83 \mathrm{~A}$ & $0.83 \mathrm{C}$ & $0.00 \mathrm{C}$ & $\begin{array}{c}\text { Mean }(A) * \\
3.22 A\end{array}$ \\
\hline Cadaman & Full Strength & $1.67 \mathrm{c}$ & $0.33 f$ & $0.00 \mathrm{~g}$ & $0.67 \mathrm{C}$ & $25.00 \mathrm{~b}$ & $8.33 c$ & $0.00 c$ & $11.11 \mathrm{CD}$ & $6.67 \mathrm{~b}$ & $0.67 \mathrm{e}$ & $0.00 \mathrm{e}$ & $2.45 B$ \\
\hline Cadarmant & Half Strength & $2.33 b$ & $0.33 f$ & $0.00 \mathrm{~g}$ & $0.89 B$ & $75.00 a$ & $8.33 c$ & $0.00 c$ & $27.78 \mathrm{~A}$ & $10.67 a$ & $0.67 \mathrm{e}$ & $0.00 \mathrm{e}$ & $3.78 \mathrm{~A}$ \\
\hline & $A \times C$ & $2.00 \mathrm{~B}$ & $0.33 \mathrm{D}$ & $0.00 \mathrm{E}$ & $\begin{array}{l}\text { Mean }(\mathrm{A})^{*} \\
0.78 \mathrm{~A}\end{array}$ & $50.00 \mathrm{~A}$ & $8.33 \mathrm{C}$ & $0.00 \mathrm{D}$ & $\begin{array}{l}\text { Mean }(\mathrm{A})^{*} \\
1944 \mathrm{~A}\end{array}$ & $8.67 \mathrm{~A}$ & $0.67 \mathrm{C}$ & $0.00 \mathrm{C}$ & $\begin{array}{l}\text { Mean }(A)^{*} \\
3.11 \mathrm{~A}\end{array}$ \\
\hline Nemaguard & $\begin{array}{l}\text { Full Strength } \\
\text { Fulf Strength }\end{array}$ & $0.67 e$ & $0.00 \mathrm{~g}$ & $0.00 \mathrm{~g}$ & $0.22 \mathrm{D}$ & $\frac{25.00 \mathrm{~b}}{3333 \mathrm{~h}}$ & $0.00 \mathrm{c}$ & $0.00 \mathrm{c}$ & $8.33 \mathrm{D}$ & $\frac{3.33 \mathrm{~d}}{4000 \mathrm{~d}}$ & $0.00 \mathrm{e}$ & $0.00 \mathrm{e}$ & $1.11 \mathrm{C}$ \\
\hline & $A \times C$ & $0.83 \mathrm{C}$ & $0.00 \mathrm{E}$ & $0.00 \mathrm{E}$ & Mean $(\mathrm{A}) *$ & $27.17 \mathrm{~B}$ & $12.50 \mathrm{C}$ & $0.00 \mathrm{D}$ & $\begin{array}{c}\text { Mean }(A)^{*} \\
13.89 \mathrm{~A}\end{array}$ & $3.67 \mathrm{~B}$ & $0.17 \mathrm{C}$ & $0.00 \mathrm{C}$ & $\begin{array}{l}\text { Mean }(\mathrm{A})^{*} \\
1.28 \mathrm{~A}\end{array}$ \\
\hline Mear & of $B \times C$ & $1.33 \mathrm{~B}$ & $0.33 \mathrm{C}$ & $0.00 \mathrm{D}$ & $\begin{array}{c}\text { Mean } \\
(\mathrm{B})^{* * *}\end{array}$ & $27.78 \mathrm{~B}$ & $5.56 \mathrm{D}$ & $0.00 \mathrm{E}$ & $\begin{array}{l}\text { Mean } \\
(B)^{* * *}\end{array}$ & $5.22 \mathrm{~B}$ & $0.44 \mathrm{C}$ & $0.00 \mathrm{C}$ & $\begin{array}{l}\text { Mean } \\
(\mathrm{B})^{* * *}\end{array}$ \\
\hline Meal & of $(C)$ & $2.11 \mathrm{~A}$ & $0.22 \mathrm{C}$ & $0.00 \mathrm{D}$ & $0.56 \mathrm{~B}$ & $61.11 \mathrm{~A}$ & $\frac{13.89 \mathrm{C}}{9.72 \mathrm{~B}}$ & $0.00 \mathrm{E}$ & $11.11 \mathrm{~B}$ & $8.89 \mathrm{C}$ & $0.67 \mathrm{C}$ & $0.00 \mathrm{C}$ & $\frac{1.89 \mathrm{~B}}{3.19 \mathrm{~A}}$ \\
\hline & of $(C)$ & $1.72 \mathrm{~A}$ & $0.28 \mathrm{~B}$ & $0.00 \mathrm{C}$ & $0.78 \mathrm{~A}$ & $44.44 \mathrm{~A}$ & $9.72 \mathrm{~B}$ & $0.00 \mathrm{C}$ & $25.00 \mathrm{~A}$ & $7.06 \mathrm{~A}$ & $0.56 \mathrm{~B}$ & $0.00 \mathrm{~B}$ & $3.19 \mathrm{~A}$ \\
\hline & Full Strength & $1.33 \mathrm{~b}$ & $0.33 d$ & $0.00 \mathrm{~d}$ & $0.56 \mathrm{BC}$ & $25.00 \mathrm{de}$ & $8.33 \mathrm{fg}$ & $0.00 \mathrm{~g}$ & $11.11 \mathrm{BC}$ & $3.67 \mathrm{e}$ & $1.33 \mathrm{~h}$ & $0.00 \mathrm{i}$ & $1.67 \mathrm{E}$ \\
\hline Garnem & Half S & & $0.33 d$ & $0.00 \mathrm{~d}$ & & $91.67 a$ & $16.67 \mathrm{ef}$ & $0.00 \mathrm{~g}$ & & $11.00 \mathrm{~b}$ & $2.33 \mathrm{~g}$ & $0.00 \mathrm{i}$ & $4.44 \mathrm{~B}$ \\
\hline $\mathrm{Mec}$ & $A \times C$ & $2.50 \mathrm{~A}$ & $0.33 \mathrm{C}$ & $0.00 \mathrm{D}$ & $\begin{array}{l}\text { Mean }(A)^{*} \\
0.94 \mathrm{~A}\end{array}$ & $58.33 \mathrm{~A}$ & $12.50 \mathrm{C}$ & $0.00 \mathrm{D}$ & $\begin{array}{c}\text { Mean (A)* } \\
23.61 \mathrm{~A}\end{array}$ & $7.33 B$ & $1.83 \mathrm{E}$ & $0.00 \mathrm{~F}$ & $\begin{array}{c}\text { Mean }(\mathrm{A})^{*} \\
3.06 \mathrm{~A}\end{array}$ \\
\hline Cadaman & $\begin{array}{l}\text { Full Strength } \\
\text { Half Strength }\end{array}$ & $1.33 \mathrm{~b}$ & $0.67 \mathrm{c}$ & $0.00 \mathrm{~d}$ & $0.67 \mathrm{~B}$ & $33.33 \mathrm{~cd}$ & $16.67 \mathrm{ef}$ & $0.00 \mathrm{~g}$ & & $5.33 d$ & $3.40 \mathrm{e}$ & $0.00 \mathrm{i}$ & $2.91 \mathrm{C}$ \\
\hline & Half S & & $0.33 d$ & $0.00 d$ & & $75.00 \mathrm{~b}$ & $16.67 \mathrm{ef}$ & $0.00 \mathrm{~g}$ & & $12.13 a$ & $3.00 \mathrm{f}$ & $0.00 \mathrm{i}$ & $\begin{array}{l}5.04 \mathrm{~A} \\
\text { ean (A)* }\end{array}$ \\
\hline Mea & $A \times C$ & $2.50 \mathrm{~A}$ & $0.50 \mathrm{C}$ & $0.00 \mathrm{D}$ & $\begin{array}{l}\text { Mean (A)* } \\
1.00 \mathrm{~A}\end{array}$ & $54.17 \mathrm{~A}$ & $16.67 \mathrm{C}$ & $0.00 \mathrm{D}$ & $\begin{array}{c}\text { Mean }(A) * \\
23.61 A\end{array}$ & $8.73 \mathrm{~A}$ & 3.20D & $0.00 \mathrm{~F}$ & $\begin{array}{l}\text { lean }(A)^{*} \\
3.98 \mathrm{~A}\end{array}$ \\
\hline Nemaguard & $\begin{array}{l}\text { Full Strength } \\
\text { Half Strength }\end{array}$ & $\begin{array}{l}0.67 \mathrm{c} \\
1.33 \mathrm{~b}\end{array}$ & $\begin{array}{l}0.00 d \\
0.00 d\end{array}$ & $0.00 d$ & $\begin{array}{l}0.22 \mathrm{D} \\
0.44 \mathrm{C}\end{array}$ & $\frac{25.00 \mathrm{de}}{41.67 \mathrm{~g}}$ & $\frac{0.00 \mathrm{~g}}{0.00 \mathrm{~g}}$ & $\frac{0.00 \mathrm{~g}}{0.00 \mathrm{~g}}$ & $\begin{array}{c}.33 \mathrm{C} \\
13.89 \mathrm{BC}\end{array}$ & $\frac{3.00 \mathrm{f}}{7.33 \mathrm{c}}$ & $\begin{array}{l}0.00 i \\
0.00 i\end{array}$ & $\frac{0.00 i}{0.00 i}$ & $\frac{1.00 \mathrm{~F}}{2.44 \mathrm{D}}$ \\
\hline Mea & $A \times C$ & $1.00 \mathrm{~B}$ & $0.00 \mathrm{D}$ & $0.00 \mathrm{D}$ & $\begin{array}{c}\text { Mean }(A) * \\
0.33 A\end{array}$ & $33.33 B$ & $0.00 \mathrm{D}$ & $0.00 \mathrm{D}$ & $\begin{array}{c}\text { Mean }(A)^{*} \\
11.11 \mathrm{~A}\end{array}$ & $5.17 \mathrm{C}$ & $0.00 \mathrm{~F}$ & $0.00 \mathrm{~F}$ & $\begin{array}{c}\text { Mean }(\mathrm{A}) * \\
1.72 \mathrm{~A}\end{array}$ \\
\hline $\mathrm{Me}$ & of $B \times C$ & $1.11 \mathrm{~B}$ & $0.33 \mathrm{C}$ & $0.00 \mathrm{D}$ & $\begin{array}{c}\text { Mean } \\
(\mathrm{B}) * * * *\end{array}$ & $27.78 \mathrm{~B}$ & $8.33 \mathrm{C}$ & $0.00 \mathrm{D}$ & $\begin{array}{l}\text { Mean } \\
(\mathrm{B})^{* * *}\end{array}$ & $4.00 \mathrm{~B}$ & $1.58 \mathrm{C}$ & $0.00 \mathrm{D}$ & $\begin{array}{l}\text { Mean } \\
(\mathrm{B}) * * *\end{array}$ \\
\hline & & $2.89 \mathrm{~A}$ & & $0.00 \mathrm{D}$ & $0.48 \mathrm{~B}$ & $69.44 \mathrm{~A}$ & $11.11 \mathrm{C}$ & 0.0 & j4B & $\frac{10.15 \mathrm{~A}}{7}$ & $1.78 \mathrm{C}$ & $0.00 \mathrm{D}$ & $1.86 \mathrm{~B}$ \\
\hline Mea & (C) & $2.00 \mathrm{~A}$ & & & $1.04 \mathrm{~A}$ & $48.61 \mathrm{~A}$ & $9.72 \mathrm{~B}$ & & & $7.08 \mathrm{~A}$ & & $0.00 \mathrm{C}$ & $3.98 \mathrm{~A}$ \\
\hline
\end{tabular}

$*, * *, * * *$ Refer to specific effect of rootstock treatment, different concentration of IBA and medium strength respectively. Capital and small letters were used for distinguishing between values of specific factors and the interaction effects respectively. Whereas, means in each column followed by the same letter/s are not significantly different at $5 \%$ level.
(A) = Rootstock type
(B) = medium strength
(C) = IBA concentration 
Table 6. Specific and interaction effects of different medium strength and medium type on survival ratio, plant height (cm )and number of leaves during acclimization stage of three peach rootstocks in 2011 and 2012 seasons.

\begin{tabular}{|c|c|c|c|c|c|c|c|c|c|c|}
\hline \multirow{2}{*}{\multicolumn{2}{|c|}{ Rootstock }} & \multicolumn{3}{|c|}{ Survival ratio } & \multicolumn{3}{|c|}{ Plant height $(\mathrm{cm})}$. & \multicolumn{3}{|c|}{ No. of leaves } \\
\hline & & $\begin{array}{l}\text { Sand+ } \\
\text { Vermiculit }\end{array}$ & $\begin{array}{l}\text { Sand+ Peat } \\
\text { moss }\end{array}$ & Mean $A \times B$ & $\begin{array}{l}\text { Sand+ } \\
\text { Vermiculit }\end{array}$ & $\begin{array}{l}\text { Sand+ Peat } \\
\text { moss }\end{array}$ & Mean $A \times B$ & $\begin{array}{l}\text { Sand+ } \\
\text { Vermiculit }\end{array}$ & Sand+ Peat & Mean $A \times B$ \\
\hline \multirow[b]{2}{*}{ Garnem } & Full strength & $5.56 \mathrm{e}$ & $16.67 \mathrm{~cd}$ & $11.11 \mathrm{C}$ & $4.67 c-e$ & 2011 & 5.00AB & $3.67 \mathrm{e}$ & $5.00 \mathrm{bc}$ & 4.33D \\
\hline & $\begin{array}{c}\text { Half } \\
\text { strength }\end{array}$ & $16.67 \mathrm{~cd}$ & $33.33 a$ & $25.00 \mathrm{~A}$ & $3.67 \mathrm{e}$ & $7.00 \mathrm{a}$ & $5.33 \mathrm{AB}$ & $3.67 \mathrm{e}$ & $5.67 \mathrm{~b}$ & $4.67 C D$ \\
\hline \multicolumn{2}{|c|}{ Mean $\mathrm{A} \times \mathrm{C}$} & $11.11 \mathrm{C}$ & $25.00 \mathrm{~A}$ & $\begin{array}{l}\text { Mean }(A)^{*} \\
18.06 A\end{array}$ & $4.17 \mathrm{C}$ & $6.17 \mathrm{~A}$ & $\begin{array}{l}\operatorname{Mean}(A)^{*} \\
5.17 A\end{array}$ & 3.67D & $5.33 \mathrm{~B}$ & $\begin{array}{l}\text { Mean }(\mathrm{A})^{*} \\
4.50 \mathrm{~B}\end{array}$ \\
\hline \multirow[b]{2}{*}{ Cadaman } & Full strength & $5.56 \mathrm{e}$ & $11.11 \mathrm{de}$ & $8.34 \mathrm{C}$ & $5.00 \mathrm{~cd}$ & $4.67 \mathrm{c}-\mathrm{e}$ & $4.83 \mathrm{~B}$ & $4.00 \mathrm{de}$ & $5.00 \mathrm{bc}$ & $4.50 \mathrm{CD}$ \\
\hline & $\begin{array}{c}\text { Half } \\
\text { strength }\end{array}$ & 11.11de & $27.78 a b$ & $19.44 \mathrm{~B}$ & $5.00 \mathrm{~cd}$ & $6.33 a b$ & $5.67 \mathrm{~A}$ & $4.67 \mathrm{~cd}$ & $5.67 \mathrm{~b}$ & $5.17 A B$ \\
\hline \multicolumn{2}{|c|}{ Mean A x C } & $8.34 \mathrm{C}$ & $19.44 \mathrm{~B}$ & $\begin{array}{l}\text { Mean }(A)^{*} \\
13.89 \mathrm{~B}\end{array}$ & $5.00 \mathrm{~B}$ & $5.50 \mathrm{AB}$ & $\begin{array}{l}\text { Mean }(A) * \\
5.25 A\end{array}$ & $4.33 \mathrm{C}$ & $5.33 \mathrm{~B}$ & $\begin{array}{l}\text { Mean }(A)^{*} \\
4.83 A^{*}\end{array}$ \\
\hline \multirow{2}{*}{ Nemaguar } & Full strength & $5.56 \mathrm{e}$ & 11.11de & $8.34 \mathrm{C}$ & 4.33de & $5.33 b-d$ & $4.83 \mathrm{~B}$ & 4.00de & $5.67 \mathrm{~b}$ & $4.83 B C$ \\
\hline & $\begin{array}{l}\text { Half } \\
\text { strength }\end{array}$ & $11.11 \mathrm{de}$ & $22.22 \mathrm{bc}$ & 16.67B & $5.33 \mathrm{~b}-\mathrm{d}$ & $5.67 \mathrm{bc}$ & $5.50 \mathrm{AB}$ & $4.33 c-e$ & $6.33 a$ & $5.33 \mathrm{~A}$ \\
\hline \multicolumn{2}{|c|}{ Mean A x C } & $8.34 \mathrm{C}$ & $16.67 \mathrm{~B}$ & $\begin{array}{l}\text { Mean }(\mathrm{A}){ }^{*} \\
12.50 \mathrm{~B}\end{array}$ & $4.83 B C$ & $5.50 \mathrm{AB}$ & $\begin{array}{l}\operatorname{Mean}(A) * \\
5.17 A\end{array}$ & $4.17 \mathrm{C}$ & $6.00 \mathrm{~A}$ & $\begin{array}{c}\text { Mean }(A) * \\
5.08 A\end{array}$ \\
\hline \multirow{2}{*}{\multicolumn{2}{|c|}{ Mean of $B \times C$}} & $5.56 \mathrm{C}$ & 12.97B & $\begin{array}{l}\text { Mean } \\
(B)^{* *}\end{array}$ & 4.67B & $5.11 \mathrm{~B}$ & $\begin{array}{l}\text { Mean } \\
\text { (B)** }\end{array}$ & $3.89 \mathrm{C}$ & $5.22 \mathrm{~B}$ & $\begin{array}{l}\text { Mean } \\
(B)^{* * *}\end{array}$ \\
\hline & & $12.96 \mathrm{~B}$ & $27.78 \mathrm{~A}$ & $9.26 \mathrm{~B}$ & $4.67 \mathrm{~B}$ & $6.33 \mathrm{~A}$ & $4.89 \mathrm{~B}$ & $4.22 \mathrm{C}$ & $5.89 \mathrm{~A}$ & $4.56 \mathrm{~B}$ \\
\hline \multicolumn{2}{|c|}{ Mean of $(C)^{* * *}$} & $9.26 \mathrm{~B}$ & $20.37 \mathrm{~A}$ & $20.37 \mathrm{~A}$ & 4.67B & $\begin{array}{l}5.72 A \\
2012\end{array}$ & $5.50 \mathrm{~A}$ & $4.06 \mathrm{~B}$ & $5.56 \mathrm{~A}$ & $5.06 \mathrm{~A}$ \\
\hline \multirow{2}{*}{ Garnem } & Full strength & $11.11 \mathrm{~d}$ & $22.22 \mathrm{c}$ & $16.67 \mathrm{C}$ & $3.67 \mathrm{~cd}$ & $4.33 c$ & $4.00 \mathrm{~B}$ & $4.00 c$ & $4.33 \mathrm{c}$ & 4.17B \\
\hline & $\begin{array}{l}\text { Half } \\
\text { strength }\end{array}$ & $11.11 \mathrm{~d}$ & $44.44 a$ & $27.78 \mathrm{~A}$ & $2.33 \mathrm{fg}$ & 6.33a & $4.33 \mathrm{AB}$ & $3.67 c d$ & $6.00 a b$ & $4.83 \mathrm{~A}$ \\
\hline \multicolumn{2}{|c|}{ Mean A x C } & 11.11D & $33.33 \mathrm{~A}$ & $\begin{array}{l}\operatorname{Mean}_{22.23}(\mathrm{~A})^{*} \\
\end{array}$ & $3.00 \mathrm{C}$ & $5.33 \mathrm{~A}$ & $\begin{array}{l}\operatorname{Mean}(A) * \\
4.17 A\end{array}$ & $3.83 \mathrm{D}$ & $5.17 \mathrm{C}$ & $\begin{array}{l}\text { Mean }(\mathrm{A})^{*} \\
4.50 \mathrm{~A}\end{array}$ \\
\hline \multirow[b]{2}{*}{ Cadaman } & Full strength & $16.67 \mathrm{~cd}$ & $16.67 \mathrm{~cd}$ & $16.67 \mathrm{C}$ & $3.00 d-f$ & $2.67 \mathrm{e}-\mathrm{g}$ & $2.83 \mathrm{C}$ & $3.00 \mathrm{~d}$ & $6.33 a$ & $4.67 \mathrm{AB}$ \\
\hline & $\begin{array}{l}\text { Half } \\
\text { strength }\end{array}$ & $22.22 \mathrm{c}$ & $33.33 b$ & $27.78 \mathrm{~A}$ & 3.33de & $6.00 \mathrm{ab}$ & $4.67 \mathrm{~A}$ & $3.00 \mathrm{~d}$ & $6.67 a$ & $4.83 \mathrm{~A}$ \\
\hline \multicolumn{2}{|c|}{ Mean A x C } & $19.45 \mathrm{C}$ & $25.00 \mathrm{~B}$ & $\begin{array}{l}\text { Mean }(A) * \\
22.22 A\end{array}$ & $3.17 \mathrm{C}$ & $4.33 \mathrm{~B}$ & $\begin{array}{l}\text { Mean }(A) * \\
3.75 A\end{array}$ & $3.00 \mathrm{E}$ & $6.50 \mathrm{~A}$ & $\begin{array}{l}\text { Mean }(A) * \\
4.75 A\end{array}$ \\
\hline \multirow{2}{*}{ Nemaguar } & $\begin{array}{l}\text { Full strength } \\
\text { Halt }\end{array}$ & $11.11 \mathrm{~d}$ & $11.11 \mathrm{~d}$ & $11.11 \mathrm{D}$ & $2.00 \mathrm{~g}$ & $5.33 \mathrm{~b}$ & $3.6 / \mathrm{B}$ & $3.6 / \mathrm{cd}$ & $5.33 \mathrm{~b}$ & $4.50 \mathrm{AB}$ \\
\hline & $\begin{array}{c}\text { Hall } \\
\text { strength }\end{array}$ & $11.11 d$ & $33.33 b$ & $22.22 \mathrm{~B}$ & $2.00 \mathrm{~g}$ & $6.00 a b$ & $4.00 \mathrm{~B}$ & $4.00 \mathrm{c}$ & $6.00 a b$ & $5.00 \mathrm{~A}$ \\
\hline \multicolumn{2}{|c|}{ Mean A x C } & 11.11D & $22.22 \mathrm{BC}$ & $\begin{array}{l}\text { Mean }(A)^{*} \\
16.67 \mathrm{~B}\end{array}$ & $2.00 \mathrm{D}$ & $5.67 \mathrm{~A}$ & $\begin{array}{l}\text { Mean }(\mathrm{A})^{*} \\
3.83 \mathrm{~B}\end{array}$ & 3.83D & $5.67 \mathrm{~B}$ & $\begin{array}{l}\text { Mean }(A) * \\
4.75 A\end{array}$ \\
\hline \multirow{2}{*}{\multicolumn{2}{|c|}{ Mean of $B \times C$}} & $12.97 \mathrm{C}$ & $16.67 \mathrm{~B}$ & $\begin{array}{l}\text { Mean } \\
(B)^{* *}\end{array}$ & $2.89 \mathrm{C}$ & $4.11 \mathrm{~B}$ & $\begin{array}{l}\text { Mean } \\
\text { (B)** }\end{array}$ & $3.56 \mathrm{C}$ & $5.33 \mathrm{~B}$ & $\begin{array}{l}\text { Mean } \\
(\mathrm{B})^{* *}\end{array}$ \\
\hline & & $\begin{array}{l}\frac{14.82 \mathrm{BC}}{13.89 \mathrm{~B}} \\
\end{array}$ & $\begin{array}{l}37.03 \mathrm{~A} \\
26.85 \mathrm{~A}\end{array}$ & $\begin{array}{l}14.82 \mathrm{~B} \\
25.93 \mathrm{~A}\end{array}$ & $\begin{array}{l}2.56 \mathrm{C} \\
2.72 \mathrm{~B}\end{array}$ & $\begin{array}{l}6.11 \mathrm{~A} \\
5.11 \mathrm{~A}\end{array}$ & $\begin{array}{l}3.50 \mathrm{~B} \\
4.33 \mathrm{~A}\end{array}$ & $\begin{array}{l}3.56 \mathrm{C} \\
3.56 \mathrm{~B}\end{array}$ & $\begin{array}{l}6.22 \mathrm{~A} \\
5.78 \mathrm{~A}\end{array}$ & $\begin{array}{l}4.44 \mathrm{~B} \\
4.89 \mathrm{~A}\end{array}$ \\
\hline
\end{tabular}
specific factors and the interaction effects respectively. Whereas, means in each column followed by the same letter/s are not significantly different at $5 \%$ level.

(A) $=$ Rootstock type
(B) $=$ medium strength

(C) $=$ potting mixture 


\section{3-B- Biochemical fingerprint studies:-}

3- B - 1- Protein related index:

The electrophoretic banding pattern of proteins extracted from leaves of the three peach rootstocks were shown in table (7) and figure (5) their densitometric analysis was illustrated. The presence or absence of bands was expressed in (+) and (-) respectively.

Results of leaves SDS- PAGE revealed a total number of (5) , (3) \& (6) protein bands with molecular weights (MW) ranged from about75.528 to $12.400 \mathrm{KDa}$ in Garnem , Cadaman and Nemaguared rootstocks. A total of $57.14 \%$ polymorphism was detected. These variations in SDS-PAGE banding patterns were used to generate dendrogam using statistical package for generate dendrogram using Statistical Package for Social Science (SPSS) computer program, figure(6). The genetic similarity and phylogenetic relationship between the rootstocks were categorized in two main groups. The first group ( Garnem and Cadaman rootstocks)was higher in their genetic similarity than the second group ( Nemaguard rootstock). The bands number 1,2 and 7 with molecular weights $75.528,54.184$ and $12.400 \mathrm{KDa}$ were found in three rootstocks. These bands may be a marker for some characteristics (Aseptic culture and survival \%) at establishment stage and (number of roots, rooting \% and root length) at root formation. Whereas, the band number 3 may be a marker in Garnem rootstock for other characteristics (Aseptic culture and survival \%) at establishment stage and (number of roots, rooting \% and root length) at root formation. Whereas, the band number 3 may be a marker in Garnem rootstock for other characteristics (number of shoots and dry weight) at multiplication and (survival $\%$ and plant length) at Acclimation. The bands number 4 and 5 with molecular weights 28.838 and $23.299 \mathrm{KDa}$ may be markers in Nemaguared rootstock for characteristics of number of leaves at establishment stage and callus at rooting stage. In this regard, Bray 1995 mentioned that that the function of the inducible proteins have not been clearly established, and predicted functions may be proposed on basis of deduced amino acid sequences. 
Table 7. Protein banding patterns of three peach rootstocks.

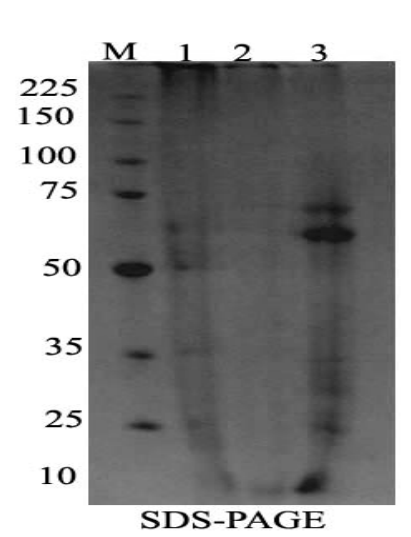

\begin{tabular}{|c|l|c|c|c|}
\hline $\begin{array}{c}\text { Band } \\
\text { No. }\end{array}$ & MW & Garnem & Cadaman & Nemaguared \\
\hline 1 & 75.528 & + & + & + \\
\hline 2 & 54.184 & + & + & + \\
\hline 3 & 30.094 & + & - & - \\
\hline 4 & 28.838 & - & - & + \\
\hline 5 & 23.299 & - & - & + \\
\hline 6 & 17.873 & + & - & + \\
\hline 7 & 12.400 & + & + & + \\
\hline & total & 5 & 3 & 6 \\
\hline
\end{tabular}

Polymorphic $=4$

Polymorphic $\%=4 / 7 \times 100=57.14 \% . \quad(+)=$ present of bands.

$(-)=$ Absent of bands.

Figure 5. SDS - PAGE of water - soluble banding pattern of three peach rootstocks.
(1) Garnem
(2) Cadaman
(3) Nemaguard

Figure 6. - Dendrogram demonstrated the relation between different peach rootstocks on SDS-PAGE.

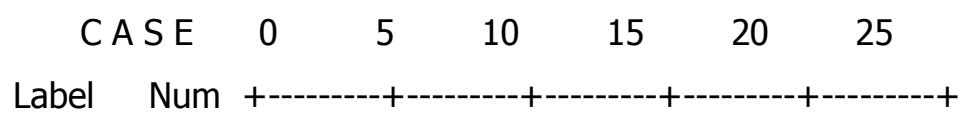

Garnem 1

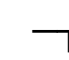

\section{Cadaman $2-$}

Nemaguared 3

\section{Conclusion}

It can be concluded that Garnem , Cadaman and Nemaguard rootstocks can be micro- propagate with shoot tips and nodal cutting . MS medium containing 2.0 $\mathrm{mg} /$ I BA was suitable to induce best shoot number during proliferation stage. $0.1 \mathrm{mg} /$ I IBA with half strength MS medium induced highest root numbers, rooting percentage and root length during rooting stage. Sand + peat moss potting mixture gaved good survival, plant height and number of leaves during acclimatization stage. 


\section{REFERENCES}

1. Ahmad, T. , Ur-Rahman ,H., Ahmad , C. M. S. and laghari , M.H . 2003. Effect of culture media and growth regulators on micropropagation of peach rootstock Gf 677.pakistan journal of botany ,35 [3] : 331-338.

2. Balla , I. and Kirilla, z. 2006. Micropropagation of peach rootstocks and cultivars. Acta Horticulturae 725 vol. 1 : 511 -516 (6) ref

3. Balttistini, A. and paoli , G. de. 2002. large scale micropropagation of several peach rootstocks. Acta Horticulturae [592]:29-33.3ref.

4. Bozenna, B. , Balla , I. , Szucs, E. and Michaczuk. 2008. Evaluation of the response of micro propagated peach rootstock "Cadaman" and cv. "Cresthaven " to Mycorrhization using Chlorophyll A fluorescence method . Journal of fruit and Ornamental plant Research vol. 16 : 243-260.

5. Bray ,E.A. 1995 . Regulation of gene expression during abiotic streeses and the role of the plant hormone abscisic acid. In : Handbook of plant and Crop physiology. [Ed]. Pessarakli, M.] CRC press, Marcel Dekker, New York, P.733 752.

6. Duncan, D.B. 1955 . Multiple range and multiple test. Biometrics, $11: 1-24$.

7. Eldeen, S.A.S., Saeed, W.T. and Hassablla, I.A. 1998. Micropropagation of peach rootstocks. Bulletin of Faculty of Agriculture University of Caio, 49 (4) : $549-562$.

8. El - Maghrably, L., Matic, S. , Fahmy, H. and Myrta, A. 2007. Viruses and viroids of stone fruits in Egypt. Journal of plant pathology, 89 [3]:427-430.

9. Fayek, M.A., Abd El -Zaher ,M.H. , Nadia, M. Mansour and Rania A. Mohamoud 2008. In vitro propagation and molecular identification of some stone fruit rootstocks. J.Biol. Chem. Environ. Sci., 3:359- 383.

10. Ferguson, J. and chaparro, J. 2004. Rootstocks for florida peaches, nectarines and plums. Journal of Nematology, 36 (1) : 20-35.

11. Fouad, M.M., Oma, A.H. and Abd El - Zaher, M.H. 1995. Factors influencing in vitro establishment and multiplication stages of peach. Acta Horticulturae, 409 : $191-196$.

12. Kamali, K., Majidi, E. and Zarghami , R. 2001. Micropropagation of Gf - 677 rootstocks (Prunus amygdalus X P. presica) . Options Mediterraneennes, 56 : $175-177$.

13. Kester D. E. and Asay R.N. 1986. Hansen 2168 and Hansen 536 : Two new pruns rootstock clones . Hort. Sci. 21 (2). pp : 331- 332 
14. Kitto S.L. and Young M.J. 1981. In vitro propagation of Carrizo citrang. Hort sci. 16: $305-306$.

15. Murashige, T. and skoog, F. 1962. A revised medium for rapid growth and bioassay with tobacco tissue cultures. Physiologia plantarum, 15:473 - 497.

16. Pinochet P. 2009. 'Greenpace' a new peach Hybrid rootstock Adapted to Mediterranean conditions Hortscience 44 (5) : 1456 - 1457

17. Polak j. and Oukropec I. 2010. The determination of sources of resistance to plum pox virus suitable for peach. ISHS Acta Horticulturae 781

18. Reeves, D.W., Couvillon G.A. and Horton , B.D. 1985 . Effect of Gibberellic acid $\left(\mathrm{GA}_{3}\right)$ on elongation and rooting of Stjuliena rootstock in vitro. Plant physiol. \& Biochemistry, 26 (3) : $252-259$.

19. Reighad G.L. 2005. Stone fruit rootstocks : current status and overview for the future. New York fruit gurrtealy. Vol (13) No. (4).

20. Saeed W.T. 2005. In vitro propagation of Hansen 2168 rootstock the $3^{\text {rd }}$ conference of Recent Technologies in Agriculture, 556 - 574.

21. Silva, A.L.da. , Rogolski, M, Moraes, L.K.A. de., Feslibino, C., crestani, L. and Guerra, M.P. 2003. In vitro establishment and multiplication of prunus rootstocks. Revista Brasileira de Fruticultura, 25 (2) : 297 - 300

22. Studier, F.W. 1973. Analysis of bacteriophage T 7 early RNAs and proteins of slab gels. J. Mol. Biol., 79 : $237-348$.

23. Unek, C. Tanriver and E. Kuden. 2011. The effect of different cytokinins on micropropagation of 'Garnem' rootstock. Acta Horticulturae (923): 195 - 197. 5 ref. 


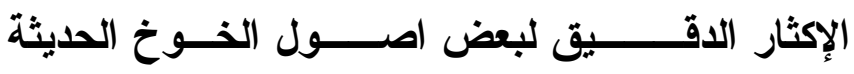

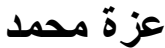

$$
\text { معه بحوث البساتين- مركز البحوث الزراعية- الجيزة- مصر }
$$

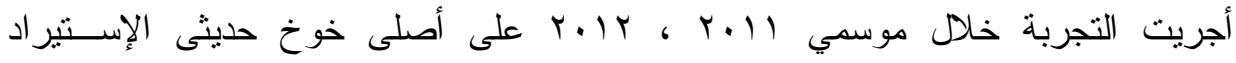
هن Cadaman ، Garnem

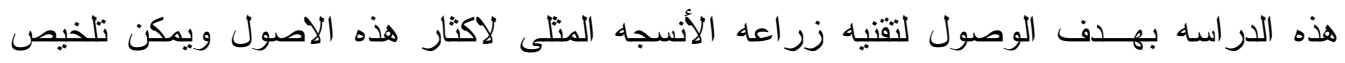

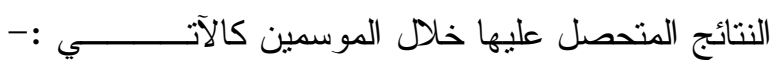

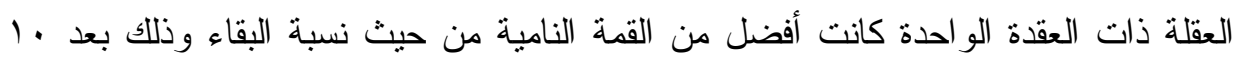
أيام من الزر اعة خلال مرحلة التأسيس • بينما بعد شهر من الزراعة إرتفعت نسبة البقاء بدون ثلوث

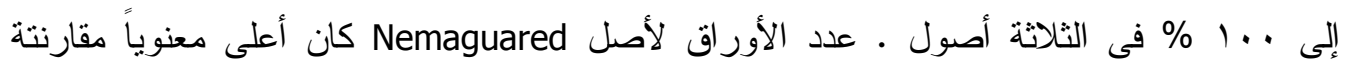
بالأصليين الآخريين لمان

وفي مرحلة الإكثار العددي أعطى أصل Garnem أعلى عدد من الأفرع ، بينما أصل r. أعطى أقل عدد . وبالإشارة إلى منظم النمو BA Cadaman جزء فى المليون أعطى أكثر فروع •

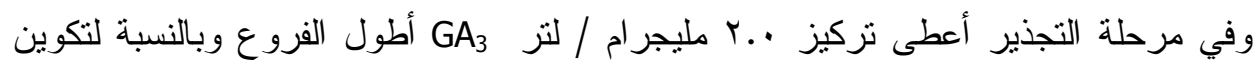

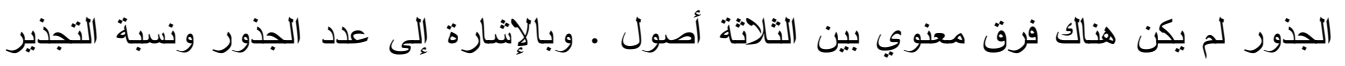

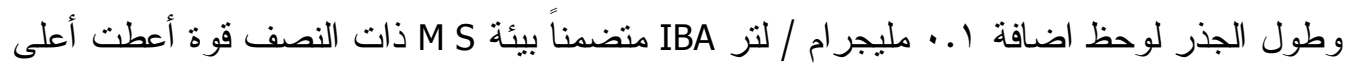
القيم

و أثثاء مرحلة الأقلمة أعطى أصل Garnem أعلى القيم من حيث نسبة البقاء ـ وكانت البيئة

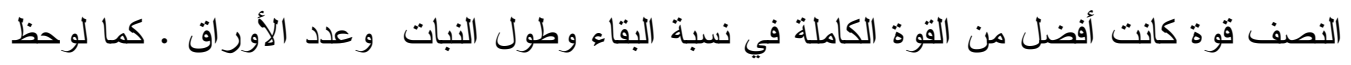
أن خليط (الرمل + البيت موس) في مرحلة الأقلمة أعطى أفضل القيم لنسبة البقاء وطول النقاء وطن النبات

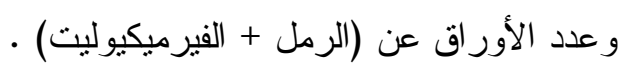

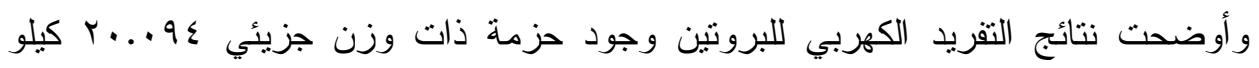
دالتون لأصل Garnem قد تكون هى المسئوله عن زيادة عدد الفروع ونسبة البقاء هذه الحزمة دئة غبر موجودة في باقي الأصول لـ لاصن 